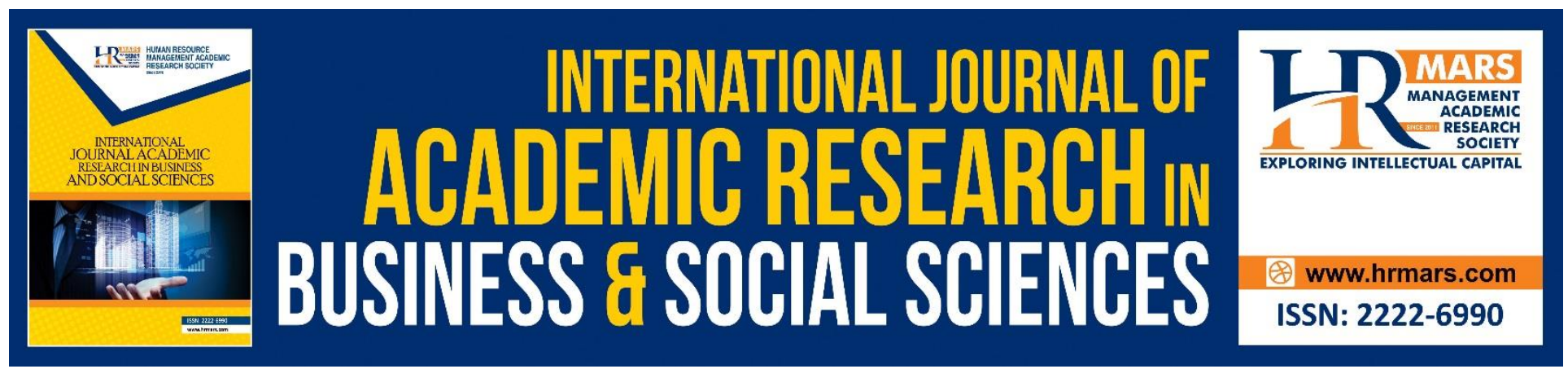

\title{
Environmental Sustainability Awareness in Selected Countries
}

\section{Haliza Abdul Rahman}

To Link this Article: http://dx.doi.org/10.6007/IJARBSS/v10-i15/8235

DOI:10.6007/IJARBSS/v10-i15/8235

Received: 10 October 2020, Revised: 12 November 2020, Accepted: 01 December 2020

Published Online: 15 December 2020

In-Text Citation: (Rahman, 2020)

To Cite this Article: Rahman, H. A. (2020). Environmental Sustainability Awareness in Selected Countries. International Journal of Academic Research in Business and Social Sciences, 10(15), 85-97.

\section{Copyright: (c) 2020 The Author(s)}

Published by Human Resource Management Academic Research Society (www.hrmars.com)

This article is published under the Creative Commons Attribution (CC BY 4.0) license. Anyone may reproduce, distribute, translate and create derivative works of this article (for both commercial and non-commercial purposes), subject to full attribution to the original publication and authors. The full terms of this license may be seen at: http://creativecommons.org/licences/by/4.0/legalcode

Special Issue: Youth and Community Wellbeing: Issues, Challenges and Opportunities for Empowerment V1, 2020, Pg. 85 - 97

Full Terms \& Conditions of access and use can be found at http://hrmars.com/index.php/pages/detail/publication-ethics 


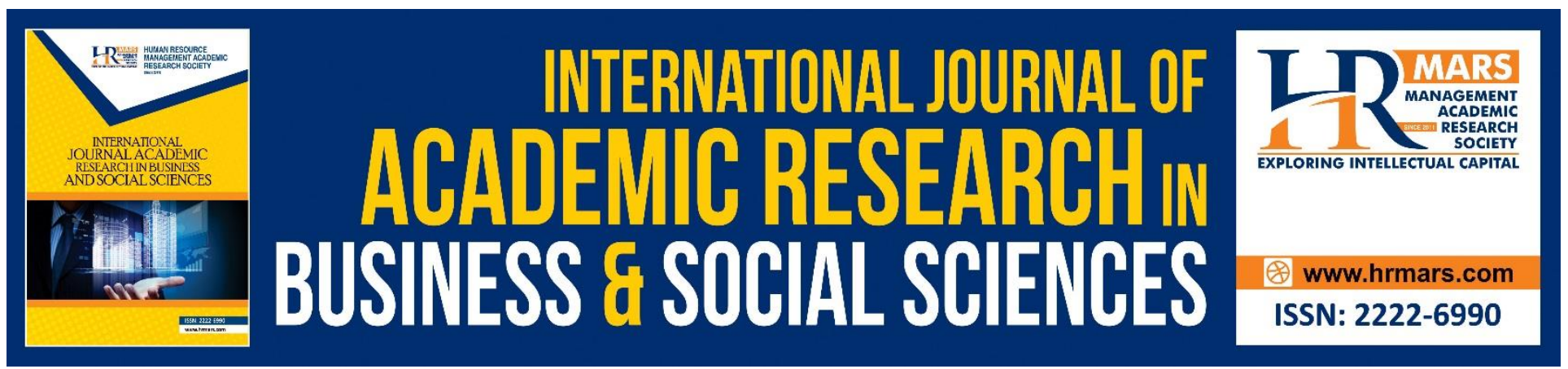

\title{
Environmental Sustainability Awareness in Selected Countries
}

\author{
Haliza Abdul Rahman \\ Institute for Social Sciences Studies (IPSAS), Putra Infoport, Universiti Putra Malaysia, \\ 43400 UPM Serdang, Selangor, Malaysia, ${ }^{2}$ Department of Environmental and Occupational \\ Health, Faculty of Medicine and Health Sciences, Universiti Putra Malaysia, 43400 UPM Serdang, \\ Selangor, Malaysia \\ Email:dr.haliza@upm.edu.my
}

\begin{abstract}
Introduction: The idea of 'sustainability' has become increasingly prominent across the globe, applied and discussed at an international, national, and community level. Objective: This paper discussed on the environmental sustainability awareness and elaborates several approaches at four countries; Switzerland, the United States of America, China, and Malaysia. Method: Secondary data are collected with regard to "environmental sustainability" and "awareness" scope matters. Result: The efficiency of implementing environmental sustainability awareness not only increases through responsibility of a single man as well as adoption of technology, but also cooperation between government and community, education and law-making; all work together to protect the environment. Conclusion: The active participation and involvement of citizen is the main key to achieve the environmental sustainability in every country.
\end{abstract}

Keywords: Environmental Awareness, Environmental Issue, Sustainability, Implementation, Responsibility

\section{Introduction}

Sustainability has been a buzzword since the 20th century. The history of the concept of sustainability is however much older. Already in $400 \mathrm{BCE}$, Aristotle referred to a Greek concept in describing household economics. This Greek household concept differed from modern ones in that the household had to be self-sustaining at least to a certain extent and could not just be consumption oriented (United Nations, 2012). Although the word has only been popular in the past century, sustainable development has its roots in ideas about sustainable forest management which were developed in the Europe during the 17th and 18th centuries (Kuhlman \& Farrington, 2010). The first time the term 'sustainable' was used "in the modern sense" was as part of the Club of Rome, in 1972. This came to the fore as a part of the publication of Limits to Growth, a report that described a particular state in which the global population would achieve balance or equilibrium. The authors 
used the word "sustainable" to describe the desirable "state of global equilibrium" (United Nations, 2012).

According to the Brundtland Report 1987, sustainability means "meet the needs of the present without compromising the ability of future generations to meet their own needs," (as cited in Dong \& Hauschild, 2017). The word or concept can be further broken down into three scopes which are social, economic and environmental (Kuhlman \& Farrington, 2010). Since the report of the Brundtland Commission, the idea of 'sustainable development' or 'sustainability' has become increasingly prominent across the globe, applied and discussed at a trans-national, international, national, regional and community level (Centre for History and Economics UK, 2008).

Sustainability is very important in protecting and maintaining the natural environment, human and ecological health as well. Using public transportation more often, reducing energy consumption and becoming eco-friendlier are some of simple steps to reducing environmental impact and to achieve environmental sustainability. Therefore, the Millennium Development Goals (MDGs) was formulated to ensure environmental sustainability in recognition of a growing concern about current consumption and production patterns leading to an unsustainable use of natural resources. Instead, ensuring environmental sustainability is one of the United Nation's eight MDG to be achieved by 2015 (Ross, 2009). Development Goal Thus, the point of this paper is to report on environmental sustainability awareness among selected countries to understand the ways in which these efforts contributed to making progress towards environmental sustainability targets of the MDGs.

\section{Methodology}

This review paper involved with secondary data which are collected from journal, proceedings, books and social media using the keywords of "environmental sustainability" and "awareness". Articles with key words in its titles or abstract were selected. This was done for articles published mainly in 20162018 and as preliminary study, thus only four countries were chosen.

\section{Results and Discussion}

Environmental destruction, sadly, often caused by anthropological activities such as development, agriculture and farming activities, industrialization and mining. Despite the positive impacts of these activities to humankind, the repercussions are becoming a burden to the surrounding environment and the living organisms that unfortunately share the same habitat and resources as that of humans. Due to this condition, there is a dire need for environmental sustainability awareness so that the current crime of environmental destruction can immediately be put on halt hence restoration and wise usage of the environment can be practiced widely, not only in Malaysia, but also around the globe.

When discussing about environmental sustainability, this means it is an act to ensure the surrounding conditions in which all living organisms live or operate are preserved for the future generation and be utilized wisely by the current generation. In view of this situation, there must be a need for awareness among the current users of the environment to not over-use the resources beyond the 
capacity that the environment can hold so that will not harm the environment in any way that can cause irreparable damages.

Lack of understanding and awareness in taking good care of the environment can lead to unsustainable environment, also making it hard for policy makers to exercise rules and law that have been enacted to encounter environmental stresses. Due to this absence of appreciation towards the environment, the society are becoming comfortable and complacent with the current deteriorating environmental situation. Either because it is not visible, or the society has become oblivious, the environment has becoming worse day by day - flash flood and land slide are becoming the typical after-effects of rain and forest fire yet another event in the summer.

Thus, in order to make these environmental stresses noticeable, environmental indicators are the perfect tools to demonstrate the syndromes of these environmental illnesses. At international level, Global Environmental Performance Index (EPI) has been introduced by the Yale Centre for Environmental Law and Policy and Columbia University's Centre for International Earth Science Information Network to monitor Environmental Public Health and Ecosystem Vitality (Neo et al, 2016). The index ranks 180 countries worldwide, with 24 performance indicators and acts as a scorecard for a country and the government on their efforts to sustain the environment (Yale, 2019).

Other than the EPI, there are also other index or measurement for the environmental health. The Organization for Economic Co-operation and Development (OECD) has its own Key Environmental Indicators that have ten key indicators, divided into two sets of Pollution Issues and Natural Resources and Assets (OECD, 2008). Each country in the world also recognizes their own measurement on the quality of the environment. For example, Canada has the Canadian Environmental Sustainability Indicators (CESI), prepared by the Environment and Climate Change Canada with the assistance from Canadian government departments (Government of Canada, 2016), while Malaysia has Malaysia EPI, designed in 2012 by the Ministry of Natural Resources and Environment and Universiti Teknologi Malaysia (UTM) (Malaysia Environmental Performance Index, 2016).

Despite the scorecards and rankings of countries participated in the Global EPI measurement, the European countries are more at a privilege to maintain their positions over the years, but it is unfortunate for the emerging economies that are performing hard to climb to at least the top ten whilst not compromising the environment (EPI, 2018; EPI, 2014). Technologies in the emerging economies such as Malaysia, might not be as advanced as that of the major economies such as Switzerland, to cater to the repercussions of development, but the least that these nations can do is to create awareness of sustainable environment within its nationals. Altin et al. (as cited in Neo et al, 2016) define environmental awareness as awareness to the environmental issues and taking a proactive involvement in environmental movements. Major economies are practicing this widely, and worth to be observed by other nations as well.

Environmental Sustainability in Selected Countries

(i) Switzerland 
Switzerland has been ranked first in the Global EPI for at least three consecutive years. The effort to sustain the environment is not championed by the government alone but supported by the people as well. From as early as primary school to the highest level of education in Switzerland, the Swiss has learned about the importance of environmental sustainability. In the lower level of kindergarten and primary school, the pupils are brought to the forest nearby their schools to learn about nature in a constructive way (Knecht, 2008). Through hands-on and direct connection with the nature, children can learn to develop empathy with their surrounding environment, in which that ability will make them into a guardian generation of the large ecosystem. In their higher education, Zurich University of Applied Sciences (ZHAW) as an example has designed a Bachelor's program that is classified under the UN World Decade of Education for Sustainable Development in Switzerland, known as Bachelor of Science in Natural Resource Sciences (Hamiti \& Wydler, 2014).

At the government level, many departments and laws related to the environment have been established. The Federal Office for the Environment (FOEN) is a division of the Federal Department of Environment, Transport, Energy and Communications, one of the seven Federal Council departments. The main roles of FOEN are to ensure the natural resources (soil, water, air, quietness and forests) are used in a sustainable manner, shield the biodiversity from natural hazards, preserve the environment and involve in the issuance of environmental policy (FOEN, 2018). The office has consumed CHF 1.9 billion, 2.7 percent of the federal budget, to carry out their responsibilities of ensuring environmental sustainability. One of their ongoing campaigns is the Respect Wildlife campaign in which two fictional puppet characters are used, Geri and Toni to facilitate awareness towards caring for the habitat. The office also released campaigns concerning noise and forest sustainability.

On the legal side, the Environmental Protection Act (EPA) was introduced on 7 October 1983 to exercise environmental protection through the power of law (House of Switzerland). The aim of the act is to "...protect people, animals and plants, their biological communities and habitats against harmful effects or nuisances and to preserve the natural foundations of life sustainability, in particular biological diversity and the fertility of the soil (EPA, 1983)." Apart from EPA, five other main federal statutes are Water Protection Act 1991 (WPA), Act on the Protection of Nature and Cultural Heritage 1966 (NCHA), Forest Act 1991 (ForA), Agriculture Act 1998 (AgricA), and Act on Non-Human Gene Technology (GTA) (Romy and Dürig, 2017). There is also the Spatial Planning Act, established in March 2013, that obliged the Swiss to utilize land space wisely and to fight the spread of urbanization or development that takes up farmland (House of Switzerland). Even though European Union's environmental regulations do not apply to Switzerland as the country is not part of the EU, but Switzerland is committed to other international environmental agreements and regulations such as the Kyoto Protocol to the United Nations Framework Convention on Climate Change (Romy and Dürig, 2017).

Despite these advances in environmental protection and preservation that have made Switzerland a champion of the EPI ranks for many years, there are challenges that come in order to produce and maintain a satisfactory sustainability outcome. One of the main challenges for the Swiss to maintain the equilibrium of the ecosystem is urbanization. In 2017, more than half of Switzerland's total 
population, or 73.76 percent, are living in the cities (Statista, 2019). According to Population Facts by the United Nations Department of Economic and Social Affairs, up till 2018, about 55 percent of the world's population are living in the city or nearby (UN, 2018). Cities are historically regions developed due to availability of natural resources required by mankind, such as water (river) for transportation that is useful for trading and connectivity purposes and as basic human needs and fertile soil for agricultural and farming purpose. As humans moved to a more resourceful habitat, increased in population carries other demands that made the change in the economical focus from agrarian community to industrial to services in the current times. With these demands come together with the basic condition requirement to fulfil the economic responsibilities such as more buildings to house the population and as place to work, soil sealing to make roads, tall skyscrapers that affect temperature and water surface runoff, pollution caused by burning of fuel and many more.

To curb these challenges, Switzerland has been doing many awareness programs and idea implementations such as introducing the Spatial Planning Act in 2013 and dismantling road as an ecological compensation to other developments (House of Switzerland; Tobias, 2013). Switzerland also encourages environmental sustainability awareness throughout education that covers early education up to the university level with a specific major dedicated to environmental awareness.

Overall, all of the Swiss people are at least decently aware that environment and humans are in symbiosis and therefore, one must take care of the other to ensure both are functioning at their highest capacity.

\section{(ii) United States of America}

As a developed country, the United States of America (USA) has a mean bio capacity of $4.3 \mathrm{gha} / \mathrm{person}$ but a mean ecological footprint of 10 gha/person, which means the country has a deficit of -5.7 gha/person (Sarkodie \& Strezov, 2018). According to the Global Footprint Network, USA is enlisted as one of the bio capacity debtors as the country is currently using, or rather 'sucking', too much natural resources from the ecosystem that the future Americans will need to rely from other countries to meet their ecological needs. Nevertheless, the USA, being a developed country, has attended to this issue and currently battling the industrial demands in order to restore environmental sustainability.

Movement to embrace sustainable and green manufacturing has been started in the USA and also gaining support from the government through the National Institute of Standards and Technology (NIST) that is part of the government's Department of Commerce. Realization to shift towards environmental-friendly and sustainable production not only caused by the need to reduce cost and manage resource utilization better, but also to answer to the demand of consumers who are growing wiser in environmental awareness (Dornfeld, 2013). Through the Manufacturing Extension Partnership (MEP) Program by NIST, many manufacturers have been on board with green and sustainable manufacturing and gain the benefits of such practice. For example, EarthColor, a commercial printing company located in New Jersey, joined the NIST program in realization to better serve the community and environment. Taking the initiatives suggested by the MEP such as Green Metrics, Operational Metrics, etc., the company managed to gain or retain USD3,000,000, cost saving 
of USD500,000, invest USD200,000 in new product or process and attracted five new employees (NJMEP, 2014). EarthColor is only one of the many sustainable-concern American manufacturers that was brave to take the path less travelled by a business in the capitalist market.

From government perspective, the U.S. Environmental Protection Agency (EPA) in its current strategic plan describes a cross-agency strategy to advance sustainable environmental outcomes and optimize economic and social outcomes through Agency decisions and actions. Sustainability has evolved from an aspiration to a growing body of practices. The evolution includes a transition from the development of broad goals toward the implementation of specific policies and programs for achieving them and the use of indicators and metrics for measuring progress. Without losing focus on implementing its existing regulatory mandates, EPA's incorporation of sustainability considerations into its decision-making about potential environmental, social, and economic outcomes involves shifting from a focus on specific pollutants in an environmental medium (air, water, or land) to a broader assessment of interactions among human, natural, and manufactured systems. EPA has indicated that it will need to consider the use of a variety of analytic tools and approaches to assess the potential sustainability-related effects of its decisions and actions in response to complex environmental challenges (National Research Council, 2014).

The EPA has begun to prioritize community engagement strategies as well to achieve its mission of protecting human health and the environment and addressing environmental injustices that disproportionately affect low-income communities and communities of color. Community engagement has been highlighted as a key facet of the agency's research efforts to support environmental justice objectives by improving the quality of information, the interpretation of data, and the ability of research to highlight strategies to reduce the burden of impact on vulnerable populations. Over the last decade, at least 42 U.S. cities have elected to pursue sustainable cities programs to improve their livability. Some programs are broad, involving smart growth efforts, and others are narrowly targeted, including bicycle ridership and pesticide-reduction programs. A recurring theme in these cities is the role of public participation in shaping and implementing these programs. Civic engagement is manifest both in the development of the sustainability program and as an explicit goal of the sustainability program (Kent, 2005).

Furthermore, currently American colleges and universities are paying increasing attention to sustainability education. For example, the California State Polytechnic University has identified its sustainability program as a priority for future growth and environmental sustainability as a core value of the University. Institutions have taken different approaches to integrate sustainability into their curriculum and establish degree programs. A few institutions developed the programs by creating new sustainability courses and prefixed the courses as such (e.g. Arizona State University). Some other institutions developed their programs by identifying courses related to sustainability from existing courses across the curriculum (e.g. Slippery Rock University). Still others developed programs by using a combination of the first two approaches: creating a few capstone sustainability courses and using existing courses across the curriculum (e.g. North Arizona University). Many of the latter two kinds of programs have been gradually developing sustainability courses to replace the use of traditional courses in the sustainability programs (e.g. Baldwin Wallace College) (Lee, 2011). 
In school, environmental sustainability programs are being implemented at the state level. As a part of the Education for Environment and Sustainability effort, environmental education is mandatory for all public schools in the state. They are taking the interdisciplinary approach as well, including environmental aspects in many different courses. "Instruction about conservation, natural resources, and the environment shall be provided at all grade levels in an interdisciplinary manner through science, the social studies, the humanities, and other appropriate areas" (Education for Environment and Sustainability, 2016). A successful environmental and sustainability education program in the U.S. is Northampton County, Virginia which the goal of their environmental education program is not only to teach students about protecting the unique environment around them, but also to involve them in diverse interdisciplinary collaboration, the creative process, advanced technology, crosscultural communication, economic development, and environment ethics and values (Flint et al, 2000). The students learn about the historical culture of the region and how their ancestors depended upon the natural environment and how people continue to depend upon it. Thus, this program is successful in teaching students environmental and sustainability topics, while improving their attention in other classes and allowing them to see the connections between the environment and other topics, such as economics, history, and even art (Flint et al, 2000).

\section{(iii) China}

As one of the world's rising economy giant, it is expected that environmental issues is one of the problems that the country is facing, apart from its economic challenges and societal concerns. In 2018 Environmental Performance Index (EPI), China stands at 120 while its regional rank is 11, beat by Malaysia at 7, Taiwan at 2 and Japan at 1 (EPI, 2018). As a norm of a climbing mega economy, China had to compromise its environment and this is shown in 2014, four years before, when the country's EPI was two steps down at 118 (EPI, 2014). The government and the people of China need a serious take on this issue before it's too late (Yale, 2018). Instead, overpopulations are often seen as the cause of China's environmental problems.

Thus, sustainability is now widely recognized as an essential component for development in China, with the Chinese government setting ambitious environmental and social targets. China's government has declared a "war on pollution" and introduced a number of green initiatives. China has taken steps to dismantle coal-fired power plants, reduce overall emission levels and cut particulate-matter emission rates. Huge progress has been made on air quality, and there are now fewer smog days in China's largest cities. The former Ministry for Environmental Protection has been transformed into the Ministry of Ecology and Environment (MEE), a new entity with broader, clearer responsibilities. The new ministry will oversee all water-related policies, for example, from ocean resources management to groundwater. Previously, these were scattered among different departments. The ministry is also in charge of policies on climate change. Furthermore, government has started collecting an environment tax to help fund its environmental policies, and is also trying to attract more green investment (World Economic Forum, 2018).

One of the causes of environmental degradation is due to farming and food industrialization. In order to produce enough meat and corps, huge areas of lands need to be specially dedicated, thus, increasing greenhouse effect and exposure of soil to direct sunlight. These effects are on top of 
expected chemical run-offs and emissions coming from factories that produce processed meat. Other than the environmental impacts of such consumerism, eating meat is reportedly contributing to higher mortality rate (Springmann et al., 2016). Traditional meat such as pork and non-traditional meat such as mutton is commonly consumed by the wealthy families (Liu et al, 2009). In the effort to reduce such meat and processed food intakes, the Chinese government has introduced an initiative known as the Chinese Dietary Guidelines (CDG) in 1989 that kills two bird with one stone - to promote better health among the Chinese and sustainable food production and consumption. China encourages its nationals to consume more fruits, vegetables and dairy products instead of meat and eggs (Lei \& Shimokawa, 2017). Not only these food types are clean foods, but also ubiquitous and cheaper than other types of food. A good impact about the guideline is that it gains more attention from the Chinese hoping to live a better, healthy life.

China's technology giants play a vital role in sustainable development as well. Tencent, Baidu and Alibaba are among the world's top 10 internet companies. Online technology particularly ecommerce, internet banking and social media is accelerating the pace of change. As example, Ant Financial, a banking subsidiary of Alibaba, is a founding partner of the Green Digital Finance Alliance. This alliance aims to use digital technology to advance green finance. Over 200 million of Ant's users signed up to Ant Forest, an app that gamifies carbon footprint tracking. The app prompts users to cut greenhouse gas emissions in real life, demonstrating the massive potential of Fintech for supporting sustainable development. By the end of January 2017, the approach had saved 150,000 tonnes of CO2 (World Economic Forum, 2018).

Towards sustainability, China has implemented and promoted environmental education since 1973, after the 1972 Stockholm conference. In higher educational institutions in China began to offer courses and majors about environment protection. For instance, Tsinghua University founded environmental engineering as a major in 1977. Beijing Normal University also began to offer graduate programs on environmental protection through the Department of Geography in 1978. In 1985, environmental education was required to be integrated into the curricula in basic education in official documents and it also required high schools to offer elective courses on environmental protection in 1992. China's Agenda 21, the White Paper on Population, Environment and Development of China in the 21st Century, was released in 1994 (Youyi, 2016). The White Paper emphasizes on the idea of sustainable development from primary education through higher education; it also seeks to heighten the public's awareness of sustainable development. It marks the beginning of the establishment and implementation of sustainable development as a national strategy. in 2002, and environmental education is practically being immersed with Environmental Sustainable Development (ESD). In this phase, environmental education has been developing all over the country, at all levels and with all forms in implementation. ESD began entering the documents, and ESD activities quickly spread across the country. In 2011, The National Action Guidelines for Environmental Communication and Education (2011-2015) was promulgated, requiring the establishment of an implementation system of environmental protection, to strengthen environmental communication and education, to enhance the people's awareness of environmental protection. The goal of cultivating an ecological civilization is to be fostered. In short, China has implemented environmental education for 40 years, and it has developed a model of environmental education with its Chinese characteristics which 
emphasizes more on awareness than environmental protection practices and government actions more than efforts of the public (Youyi, 2016).

\section{(iv) Malaysia}

Malaysia is blessed with rich biodiversity that includes one of the oldest rainforests in the world, myriads of rare flora and fauna species, pristine and virgin forests and picturesque landscapes. Thus to protect of the richest biodiversity, National Policy on the Environment (DASN) has been established for continuous economic, social and cultural progress and enhancement of the quality of life of Malaysians through environmentally sound and sustainable development. The objectives of DASN are to achieve; (1) A clean environment, safe, healthy and productive environment for present and future generations, (2) Conservation of country's unique and diverse cultural and natural heritage with effective participation by all sectors of society, and (3) Sustainable lifestyles and patterns of consumption and production. DASN seeks to integrate environmental considerations into development activities and in all related decision-making processes, to foster long-term economic growth and human development, and to protect and enhance the environment. It complements and enhances the environmental dimensions of other national policies, such as those on forestry and industry, and takes cognizance of international conventions on global concerns.

Furthermore, to materialize and utilize the natural resources and sustain the environment comprehensively, Environmental Quality Act 1974 (Act 127) (EQA) was enacted. This Act is the primary legislation dealing with environmental protection and enforcement in Malaysia in order to prevent, abate, control pollution and enhance the quality of environment. Meanwhile, the Department of Environment (DOE) was set up by the government in 1975 to administer and ensuring compliance with the provisions of the EQA and initiating enforcement proceedings in the event of a breach. Other laws were promulgated as well such as the Protection of Wildlife Act 1972 Act 76, the Fisheries Act 1985 Act 317, the National Forestry Act 1984, the National Parks Act 1980, and the Town and Country Planning Act 1976 to prevent environmental deterioration as a result of human activities. Currently, Malaysia move to a greener economy, which implies meeting development and environmental sustainability, which will take into consideration not only economic but also environmental criteria. With that in mind, the concept of 'greening' is currently gaining popularity among scientific research community and government's policy making. Instead, environmentallyfriendly products are gaining popularity, especially among the Generation-X and Generation-Y. Thus, the Malaysian government recognised green technology as the driver for economic growth. It provides vast opportunities and potentials in terms of economic generation, technology innovation and wealth creation. Green technology has vast applications across different sectors such as energy production, manufacturing, services and transportation. The introduction and implementation of economic instruments with the support of monetary and fiscal measures are essential to heighten green technology development in Malaysia. Various incentives are made available to targeted industry players to intensify potential producers and users of green technology. This includes eligible companies for activities related to green technology in furniture manufacturing such as utilisation of renewable energy, energy conservation/energy efficiency, reduction of greenhouse gas emission, import and purchase of machinery components, waste recycling, environmental protection storages, and treatment and disposal of toxic/hazardous waste. Financial and incentive supports are offered in 
terms of soft loans, pioneer status, tax and import duty exemptions, which are managed by agencies such as the Malaysia Investment Development Authority (MIDA) and Malaysian Green Technology Corporation (FDMAsia, 2020).

In agriculture sector, a wide variety of agricultural activities are running in Malaysia. Malaysia had emerged as one of the world's top producers of rubber and palm oil, driven by the birth of local commodity conglomerates. Meanwhile, smallholders were the major players for crops such as rice, fruits and vegetables. In 2020, with expected to grow at $3.5 \%$ per annum and contributing $7.8 \%$ to GDP, the agro-food and industrial commodity sub-sectors will be transformed and modernized into a high-income and sustainable sector. However, the challenging is how to maintaining high quality of agricultural products with lower environmental impacts through a sustainable economic viability and life satisfaction of farmers and community are important factors helping to meet sustainable agriculture. Thus, government tried to have an effort in promoting and publishing sustainable in agriculture by publishing Malaysian Standard in Good Agriculture Practices in year 2005 which had been done by the Department of Agriculture (DOA). Referring to the Malaysia Standards, DOA was also undertaking the positive ways in reducing the dependence of chemical fertilizer for crop production by promoting Practices of Integrated Farming System (IFS), Good Agricultural Practices (GAP) and Organic Farming (OP). Most of the Malaysian farmer especially in the small scale farm had given a good acceptance towards this effort. The development of the sector will also take into account the impact of climate change on sustainability of agricultural practices.

Despite all efforts to curb environmental issues, the most important would be from education. According to a study done by Masud and Kari (2015), education has a positive correlation to environmental awareness. In education, Malaysia has taken proactive approach for environmental awareness to be seeded within the youngest generation through the national curricula. Generally, environmental sustainability has been touched lightly in primary school Science and Moral Education/Islamic Education subjects. As example, at the higher education level, university students are also involved in the environmental awareness and restoration efforts. Higher education supposed to nurture greater environmental behavior and better understanding hence notable environmental awareness, in particular among those who study in environment-related courses.

\section{Conclusion and Recommendation}

Environmental degradation is a common episode in the life of humankind. Ever since humans inhabit the earth, anthropological activities have compromised the overall quality of the nature gradually. Without nested environmental awareness, one can simply cause massive destruction to the environment and the ecology. It is already discussed that there are many factors that can elevate environmental sustainability awareness as discussed and shown in selected countries above. The most common way is the top-down approach in which a government plays a significant role in creating a law that can then be practiced by the whole nation. Apart from 'forcing' nationals to obey by the law, government also approach the people via campaigns and education. Active involvement by the government via local authority may be micro-managing the people, but it is one effective way to ensure discipline is established first before a forced behavior become a norm in the society. 
INTERNATIONAL JOURNAL OF ACADEMIC RESEARCH IN BUSINESS AND SOCIAL SCIENCES

Vol. 10, No. 15, Youth and Community Wellbeing: Issues, Challenges and Opportunities for Empowerment V1. 2020, E-ISSN: 2222-6990 @) 2020 HRMARS

\section{Declaration}

I declare that this manuscript is my original work and it is submitted for first publication to HRMAS. The manuscript has not been published and is not being submitted or considered for publication elsewhere. The text, illustrations, or any other materials included in the manuscript contains no violation of any existing copyright and does not infringe any rights of third parties.

\section{Acknowledgements}

Special thanks to Universiti Putra Malaysia for providing a research grant (9661300) for making the study on sustainability a successful.

\section{References}

Centre for History and Economics UK. (2008). History and Sustainability. Resources for Environmental History and Education for Sustainable Development. Accessed via https://www.histecon.magd.cam.ac.uk/history-sust/. Retrieved 4 October 2020.

Dong, Y., \& Hauschild, M. Z. (2017). Indicators for Environmental Sustainability. ScienceDirect, Procedia CIRP 61: 697-702.

Dornfeld, D. A. (2013). Green Manufacturing: Fundamentals and Applications. New York: Springer Science+Business Media New York.

FDMAsia. (2020). Malaysia Goes Green. https://www.fdmasia.com/index.php/woodsustainability/item/316-malaysia-goes-green. Retrieved March 10, 2020.

FOEN, Federal Office for the Environment. (2018). OECD Environmental Performance Reviews: Switzerland 2017.

Government of Canada. (2016). Environmental Indicators. Accessed via https://www.canada.ca/en/environment-climate-change/services/environmentalindicators.html. Retrieved 11 September 2020.

Government UAE. (2019). UAE and the Agenda for Sustainable Development Excellence in Implementation. Accessed via

https://sustainabledevelopment.un.org/content/documents/20161UAE_SDGs_Report_Full_English. pdf. Retrieved 11 September 2019.

Flint, R. W., McCarter, W., \& Bonniwell, T. (2018). Interdisciplinary education in sustainability: Links in secondary and higher education. International Journal of Sustainability in Higher Education, 1(2): 191-202.

Hamiti, S. W., \& Wydler, H. (2014). Supporting the Integration of Sustainability into Higher Education Curricula - A Case Study from Switzerland. Sustainability, 6: 3291-3300.

Knecht, S. (2008). Benefits and Challenges of Forest Education in Primary Schools in the Canton of Zurich, Switzerland. Master Thesis. Institute of Environmental Sciences University of Zurich.

Kuhlman, T., \& Farrington, J. (2010). What is Sustainability? Sustainability, 2(11): 3436-3448.

Lei, L., \& Shimokawa, S. (2017). Promoting dietary guidelines and environmental sustainability in China. China Economic Review.

Liu, H., Parton, K. A., Zhou, Z. Y., \& Cox, R. (2009). At-home meat consumption in China: an empirical study. The Australian Journal of Agricultural and Resource Economics. 53(4): 485-501. 
Malaysia Environmental Performance Index 2015. (2016). Malaysia's Performance in Environmental Performance Index. Accessed via http://www.mpc.gov.my/wp-content/uploads/2016/04/EPI2016-Topline.pdf. Retrieved 11 September 2020.

Mehedi, M., \& Kari, F. (2015). Community attitudes towards environmental conservation behaviour: An empirical investigation within MPAs, Malaysia. Marine Policy, 52(C): 138-144.

National Research Council. (2014). Sustainability Concepts in Decision-Making: Tools and Approaches for the US Environmental Protection Agency. Washington, DC: The National Academies Press.

Mei, N. S., Wai, C. W. \& Rahmalan, A. (2017). Environmental Awareness and Behaviour Index for Malaysia. ScienceDirect. Procedia - Social and Behavioral Sciences, 222: 668-675.

Environmental law and practice in Switzerland: overview. Accessed via https://uk.practicallaw. thomsonreuters.com/9-596-

3045 ?transitionType $=$ Default\&contextData $=(s c$. Default $) \&$ firstPage $=$ true\&bhcp $=1 . \quad$ Retrieved 11 March 2020.

Ross, A. (2009). Modern Interpretations of Sustainable Development. Journal of Law and Society, 36(1): 32-54.

United Nations. (2012). United Nations Conference on Sustainable Development, Rio + 20 - Road to Rio. Accessible via https://rio20.un.org/resolutions-more. Retrieved 4 October 2020.

World Economic Forum. (2018). Here's how China is going green. Accessed via https://www.weforum.org/agenda/2018/04/china-is-going-green-here-s-how/. Retrieved 2 March 2020.

Yale. (2018). Environmental Performance Index.

https://epi.envirocenter.yale.edu/downloads/epi2018reportv06191901.pdf. Retrieved 6 September 2020.

Yale, Centre for Environmental Law \& Policy. (2019). Global metrics for the environment. Accessed via https://epi.envirocenter.yale.edu/. Retrieved 6 September 2020.

Youyi, T. (2016). Environmental Education in China: Development, Difficulties and Recommendations. Journal of Social Science Studies. 3(1): 31-43.

Zayed University. (2017). HCT Catalog 2017-2018. Accessed via https://www.zu.ac.ae/main/en/colleges/colleges/_college_of_technological_innovation/_IT Ext_links/ZUCatalog2018-2019.pdf. Retrieved 6 September 2020. 